\title{
PENGARUH MODAL MINIMAL INVESTASI DAN RETURN TERHADAP MINAT INVESTASI MASYARAKAT KOTA PALEMBANG DI PASAR MODAL
}

\author{
Oleh: M. Yusuf ${ }^{1}$, Yahya $^{2}$, Abd. Hamid ${ }^{3}$ \\ m.yusuf@polsri.ac.id ${ }^{1}$, yahya@polsri.ac.id ${ }^{2}$, abdoelhamid1958@gmail.com ${ }^{3}$ \\ ${ }^{1}$ (Program Studi Sarjana Terapan Manajemen Bisnis, Jurusan Administrasi \\ Bisnis, Politeknik Negeri Sriwijaya) \\ 2,3(Diploma III Administrasi Bisnis, Jurusan Administrasi Bisnis, Politeknik \\ Negeri Sriwijaya)
}

\begin{abstract}
Abstrak-Penelitian ini bertujuan untuk mengetahui pengaruh modal minimal investasi dan motivasi investasi terhadap minat investasi masyarakat Kota Palembang di pasar modal. Metode penelitian yaitu penelitian kuantitatif dengan analisis regresi linier berganda. Sampel dalam penelitian ini sebanyak 100 responden dengan tehnik purposive sampling yaitu responden yang memiliki akun di pasar modal. Pengolahan data dalam penelitian ini menggunakan aplikasi SPSS. Hasil uji partial menunjukkan bahwa modal minimal investasi berpengaruh terhadap minat investasi, namun tidak untuk variabel return. Hal ini dapat dilihat dari nilai signifikansi variabel modal minimal investasi sebesar ,000 $<0,05$, sedangkan untuk variabel return diperoleh nilai 0,319>0,05. Sedangkan hasil untuk uji simultan menunjukkan bahwa modal minimal investasi dan return berpengaruh sigifikan terhadap minat investasi.
\end{abstract}

Kata Kunci: Modal Minimal Investasi, Return, Minat Investasi

\begin{abstract}
This study aims to determine the effect of minimum investment capital and investment motivation on the investment interest of the people of Palembang in the capital market. Data analyzed used multiple regression. The sampling technique used purposive sampling with 100 respondents have identity member. Data processing in this study using the SPSS application. The results of this study explain that with the results of the $t$ test (partial) it is said that the minimum investment capital variable has an effect on investment interest while the return variable has no effect. Meanwhile, for the simultaneous test of the two variables together, it can affect the investment interest variable.
\end{abstract}

Keywords: Minimum Investment Capital, Return, Investment Interest

\section{PENDAHULUAN}

Berdasarkan data dari IDX per september 2020, jumlah perusahaan yang go-public sebanyak 677 emiten. Go public di pasar modal merupakan salah satu starategi perusahaan untuk bersaing di dunia bisnis. Hal ini disebabkan karena setiap perusahaan dituntut untuk melakukan inovasi untuk mendapatkan dana dari pihak 
luar. Pasar modal memiliki peran penting dalam menunjang perekonomian suatu negara dikarenakan pasar modal memiliki dua fungsi sekaligus, yaitu fungsi ekonomi dan fungsi keuangan.

Pasar modal merupakan tempat dimana bertemunya pihak yang kelebihan dana (investor) dengan pihak yang membutuhkan dana (perusahaan). Investor membutuhkan perusahaan sebagai sarana berinvestasi sedangkan, perusahaan membutuhkan investor sebagai sarana mendapatkan dana. Selain itu, Pasar modal memiliki peran penting dalam menunjang perekonomian suatu negara dikarenakan pasar modal memiliki dua fungsi sekaligus, yaitu fungsi ekonomi dan fungsi keuangan.

Investor merupakan salah satu unsur penting yang ada dalam kegiatan berinvestasi di pasar modal. Investasi adalah kegiatan penanaman modal satu atau lebih aset yang dimiliki, biasanya penanaman ini bersifat jangka panjang dan diharapkan berdampak positif nantinya. Perkembangan teknologi yang pesat menyebabkan mudahnya masyarakat untuk mengakses informasi mengenai perusahaan (emiten) yang akan mereka investasikan.

Pendataan investor yang melakukan transaksi di pasar modal merupakan langkah awal untuk mengidentifikasi investor mulai dari transaksi sampai penyelesaiannya.
Dengan demikian pemerintah bisa membuat suatu regulasi kebijakan terkait dengan investasi di pasar modal guna menarik minat investor. Pemberlakuan kebijakan identifikasi investor atau lebih dikenal dengan Single Investor Identification (SID) di Indonesia dimulai tahun 2011 dengan kebijakan SID untuk investor saham saja. Namun melihat masih rendahnya minat investor di pasar modal, maka pada Tahun 2015 dibuat kebijakan SID untuk investasi reksadana. Kebijakan tersebut sepertinya ampuh dimana setiap tahunnya, jumlah investor di pasar modal terus mengalami kenaikan.

Di Sumatera Selatan berdasarkan data BEI perwakilan Sumatera Selatan (2021), Single Investor Identification (SID) mengalami pertumbuhan sebesar 211,4 persen dimana tercatat pada Tahun 2019 terdapat 5.959 SID dan mengalami pertumbuhan pada Tahun 2020 menjadi 12.598 SID. Dengan meningkatnya jumlah SID ini menunjukkan bahwa terjadi penguatan investasi dan SID yang aktif di Sumatera Selatan.

Kota Palembang yang merupakan pusat pemerintahan Sumatera Selatan menunjukkan SID yang paling besar di banding wilayah lainnya di Sumatera Selatan dimana SID semenjak tahun 2017 menunjukkan tren menguat. Tabel 1 dibawah ini merupakan total pertumbuhan Single Investor Identification dari tahun 2017-2020. 
Tabel 1. Jumlah SID Kota

Palembang

\begin{tabular}{|c|c|}
\hline Tahun & Jumlah SID \\
\hline 2017 & 7.706 \\
\hline 2018 & 10.490 \\
\hline 2019 & 14.006 \\
\hline 2020 & 21.392 \\
\hline
\end{tabular}

Sumber: BEI Sumatera Selatan, 2021

Peningkatan jumlah SID ini tifdak terlepas dari upaya yang dilakukan seperti kampanye "Yuk Nabung Saham." yang dimulai pada tahun 2015. Selain itu peningkatan juga terjadi karena adanya kebijakan terkait modal minimal investasi. Modal minimal merupakan setoran awal untuk membuka rekening saat pertama kali pada pasar modal (Wibowo dan Purwohandoko, 2018). Modal minimal investasi di pasar modal yang paling rendah adalah sebesar Rp. 100.000,- sesuai dengan keputusan No. Kep0071/BEI/11/2013.

Penelitian Aini dkk. (2019) tentang pengaruh pngetahuan dan pemahaman investasi, modal minimum investasi, return, risiko dan motivasi investasi terhadap minat mahasiswa berinvestasi di pasar modal menunjukkan bahwa modal minimal tidak berpengaruh terhadap investasi. Sedangkan penelitian Purboyo dkk. (2019) terkait dengan pengaruh aktifitas galeri investasi, modal minimal investasi, persepsi risiko dan persepsi return terhadap minat investasi saham syariah menunjukkan modal minimal berpengaruh terhadap minat investasi.

Di dalam investasi sendiri, tujuan utama investor adalah untuk mendapatkan return dalam bentuk capital gain dan dividen. Return adalah pengembalian atas investasi. Namun terkadang, investor tidak dapat mencapai return yang diinginkan, malah yang didapatkan oleh investor adalah kerugian seperti capital loss, tidak mendapatkan dividen, dan bahkan kehilangan modal yang diberikan karena likuidasi perusahaan. Padahal penyebab meningkatnya investor dikalangan masyarakat sendiri antara lain modal minimal yang sangat mudah dijangkau dan return yang cenderung besar (namun harus sesuai dengan modal yang diberikan.

Untuk itu perlu dilakukan penelitian terkait dengan pengaruh modal minimal investasi dan return terhadap minat investasi masyarakat Kota Palembang di pasar modal. Adapun kerangka pemikiran dalam penelitian ini berdasarkan pada teori dan penelitian terdahulu yang digambarkan sebagai berikut:

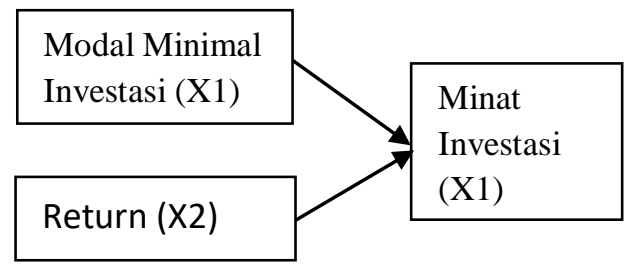

Gambar 1. Kerangka berpikir (Sumber: Data Diolah, 2021) 
Dari kerangka berpikir tersebut maka dapat dirumuskan hipotesis:

1. Diduga secara parsial ada pengaruh signifikan modal minimal investasi dan return terhadap minat investasi masyarakat di Kota Palembang

2. Diduga secara simultan ada pengaruh signifikan modal minimal investasi dan return terhadap minat investasi masyarakat di Kota Palembang

\section{METODE PENELITIAN}

Penelitian ini adalah jenis penelitian kuantitatif. Menurut Sugiyono (2018:482) penelitian kuantitatif adalah penelitian berfilsafat positif yang digunakan untuk meneliti sampel tertentu dengan tujuan untuk menguji hipotesis. Objek penelitian ini adalah investor pasar modal di Kota Palembang Populasi dalam penelitian adalah 21.392 SID sehingga dengan rumusan slovin diambil 100 responden. Teknik sampling yang digunakan adalah dengan menggunakan purposive sampling, yaitu investor yang memiliki akun di pasar modal dengan menggunakan nonprobability sampling.

Analisis data dalam penelitian ini menggunakan regresi linier berganda sebagai berikut:

$$
\mathrm{Y}=\alpha+\beta 1 \mathrm{X} 1+\beta 2 \mathrm{X} 2+\mathrm{e}
$$

Dimana minat investasi (Y), modal investasi (X1) dan return (X2), nilai Konstanta $(\alpha)$ dan nilai regresi/koefisien $(\beta)$.
Adapun defenisi operasional dalam penelitian ini sebagai berikut:

a) Modal minimal investasi adalah modal awal untuk pembukaan rekening perdana di pasar modal dengan indicator penetapan modal awal, estimasi dana untuk investasi dan hasil investasi (Riyadi, 2016).

b) Return adalah nilai yang diperoleh dari hasil dan aktifitas investasi dan tujuan utama investor melakukan investasi dengan indicator: pengetahuan return, return yang diharapkan dan sumber return (Zulpiana 2019).

c) Minat investasi adalah keingintahuan seseorang terhadap suatu hal yang membuatnya tertarik dengan indicator: keinginan mencari tahu tentang investasi di pasar modal, meluangkan waktu untuk mempelajari lebih jauh tentang investasi di pasar modal dan mencoba berinvestasi melalui pasar modal.

\section{HASIL DAN PEMBAHASAN}

Dari hasil penelitian, diketahui bahwa variabel modal minimal investasi dan return secara bersamasama berpengaruh terhadap variabel minat investasi.

1. Uji validitas

Berdasarkan hasil uji validitas dikatakan bahwa semua item pertanyaan valid karena jumlah $r$ hitung $>\mathrm{r}$ tabel. $\mathrm{r}$ tabel untuk 
penelitian ini sendiri adalah 2. Uji Reliabilitas sebesar 0,361 .

Tabel 2. Uji Reliabilitas

\begin{tabular}{|c|c|c|}
\hline Variabel & Cronbach's Alpha & Keterangan \\
\hline Modal & 0.952 & Reliable \\
Minimal & & \\
Investasi & & Reliable \\
\hline Return & 0.904 & Reliable \\
\hline Minat Invetasi & 0.883 & \\
\hline
\end{tabular}

Sumber: Data Diolah Hasil penelitian, 2021

Suatu variabel dapat dikatakan reliable jika cronbach alpha nya diatas dari 0,60 (Lupiyoadi dan Ikhsan 2015:62). Berdasarkan tabel 2 dapat dilihat bahwa ketiga item ini reliable sehingga layak untuk dijadikan quisitioner.

3. Uji T (Uji Parsial)

Tabel 3. Uji T (Uji Parsial)

\begin{tabular}{|c|c|c|}
\hline model & $\mathrm{t}$ & Sig \\
\hline Total_Modal & 10.600 &, 000 \\
\hline Total_Return & -1015 &, 319 \\
\hline
\end{tabular}

Sumber: Data Diolah Hasil penelitian, 2021

Berdasarkan tabel 3 dapat dilihat bahwa variabel modal minimal investasi berpengaruh terhadap minat investasi, namun tidak untuk variabel return. Hal ini dapat dilihat dari sig. Variabel modal memiliki sig sebesar ,000 yang mana lebih kecil dari 0,05. Sedangkan untuk variabel return lebih besar dari 0,05 yaitu sebesar 0,319 . Hal ini berarti hipotesis adanya pengaruh signifikan secara parsial modal minimal investasi terhadap minat investasi masyarakat di Kota Palembang diterima, sedangkan hipotesis return berpengaruh signifikan secara parsial terhadap minat investasi masyarakat di Kota Palembang ditolak.

4. Uji F (Uji simultan)

Tabel 4. Uji F (simultan)

\begin{tabular}{|c|c|c|}
\hline Model & F & Sig \\
\hline Regression & 62,751 &, $000^{\mathrm{b}}$ \\
\hline
\end{tabular}

Sumber: Data Diolah Hasil penelitian, 2021 
Dari hasil penelitian ini menunjukkan bahwa modal minimal investasi (X1) secara parsial berpengaruh terhadap minat investasi masyarakat di Kota Palembang, sedangkan return (X2) tidak berpengaruh secara parsial terhadap minat investasi (Y) dibuktikan dengan jumlah signifikan lebih kecil dari 0,05. Namun ketika dilakukan uji secara simultan, modal minimal (X1) dan return (X2) berpengaruh signifikan terhadap minat investasi masyarakat di Kota Palembang.

Modal minimal investasi dijadikan pertimbangan karena di dalamnya terdapat perhitungan estimasi dana untuk investasi, semakin minimum dana yang dibutuhkan akan semakin tinggi pula minat seseorang untuk berinvestasi (Rima, 2015). Semakin kecil modal yang dikeluarkan maka semakin besar minat seseorang untuk berinvestasi. Hasil dari penelitian ini yang menunjukkan adanya pengaruh signifikan modal minimal investasi terhadap minat investasi masyarakat Kota Palembang searah dengan penelitian yang dilakukan oleh Purboyo dkk. (2019) yang melakukan penelitian pengaruh aktifitas GI, modal minimal investasi, persepsi resiko dan persepsi return terhadap minat berinvestasi di saham syariah (studi kasus pada mahasiswa Uniska MAB Banjarmasin). Dengan demikian peran pasar modal di Kota Palembang sebagai sarana antara masyarakat yang ingin berinvestasi dan perusahaan yang membutuhkan dana dari investor sehingga terdapat take and give. Peningkatan minat investasi dengan modal investasi minimal membantu dalam menunjang pelaksanaan pembangunan nasional dalam rangka meningkatkan pemerataan, pertumbuhan, dan stabilitas ekonomi nasional kearah peningkatan kesejahteraan rakyat yang tertuang dalam Rencana Pembangunan Jangka Menengah Nasional 20152019 (BAPPENAS, 2014).

Return saham adalah nilai yang diperoleh sebagai hasil dari aktivitas investasi. Persepsi terhadap return adalah anggapan calon investor terhadap tingkat pengembalian dalam sebuah investasi. Hasil dari penelitian ini yang menunjukkan adanya hasil yang signifikan pengaruh return terhadap minat investasi masyarakat di Kota Palembang searah dengan penelitian yang dilakukan oleh Aini dkk (2019) mengenai pengaruh pengetahuan dan pemahaman investasi, modal minimum investasi return, risiko dan motivasi investasi terhadap minat mahasiswa berinvestasi di pasar modal (Studi pada Mahasiswa Fakultas Ekonomi dan Bisnis Kota Malang).

\section{KESIMPULAN}

Secara parsial modal minimal investasi berpengaruh terhadap minat investasi, sedangkan return tidak 
berpengaruh secara signifikan terhadap minat investasi. Sedangkan secara simultan variable modal minimal dan return berpengaruh secara signifikan.

\section{DAFTAR PUSTAKA}

Aini, N., Maslichah, M., \& Junaidi, J. (2019). Pengaruh Pengetahuan dan Pemahaman Investasi, Modal Minimum Investasi Return, Risiko dan Motivasi Investasi Terhadap Minat Mahasiswa Berinvestasi di Pasar Modal (Studi pada Mahasiswa Fakultas Ekonomi dan Bisnis Kota Malang). Jurnal Ilmiah Riset Akuntansi, $8(05)$

BAPPENAS. (2014). Rencana Pembangunan Jangka Menengah Nasional 2015$2019 . \quad$ Dikutip dari: https://www.bappenas.go.id/id/ data-dan-informasiutama/dokumen-perencanaandan-pelaksanaan/dokumenrencana-pembangunannasional/rpjp-20052025/rpjmn-2015-2019/

BEI perwakilan Sumatera Selatan. (2021). Statistik Data Investor. Palembang

$\begin{array}{ccr}\text { Keputusan } & \text { No. } & \text { Kep- } \\ \text { 0071/BEI/11/2013. } & \text { Modal } \\ \text { minimal investasi } \\ \text { modal }\end{array}$

Lupiyoadi, Rambat dan Ridho Bramulya Ikhsan. (2015). Praktikum Metode Riset Bisnis. Jakarta: Salemba Empat.

Purboyo, P. Zulfikar, R. \& Wicaksono, T. (2020). Pengaruh Aktifitas Galeri Investasi, Modal Minimal
Investasi, Persepsi Risiko dan Persepsi Return Terhadap Minat Investasi Saham Syariah (Studi pada Mahasiswa Uniska MAB Banjarmasin). JWM (Jurnal Wawasan Manajemen), 7(2). 136-150.

Riyadi, Adha. (2016). Analisis Faktor-Faktor yang Mempengaruhi Minat Mahasiswa untuk Berinvestasi di Pasar Modal (Studi pada Mahasiswa Fakultas Ekonomi dan Bisnis Islam UIN Sunan Kalijaga. Tesis. Program Studi Keuangan Syariah Fakultas Ekonomi dan Bisnis Islam UIN Sunan Kalijaga. Yogyakarta.

Saputra, D. (2018). Pengaruh Manfaat, Modal, Motivasi, dan Edukasi Pasar Modal terhadap Minat dalam Berinvestasi di Pasar Modal. Future: Jurnal Manajemen dan Akuntansi, 5(2), 178-190. Semarang: Badan Penerbit Universitas Diponegoro.

Sugiyono. (2018) Metode Penelitian Dan Pengembangan. Bandung: Alfabeta.

Wibowo, A \& Purwohandoko. (2018) .Pengetahuan Investasi Kebijakan Modal MinimalInvestasi, Pelatihan PasarModal Terhadap MinatInvestasi (Studi Kasus Pada Mahasiswa FE Unesa YangTerdaftar di GaleriInvestasi FE Unesa)

Zulpiana. (2019). Pengaruh Motivasi, Pelatihan dan Return Saham Terhadap Minat Investasi STIE NOBEL Indonesia Makassar Berinvestasi di Pasar Modal. 
Skripsi: Sekolah Tinggi Ilmu

Ekonomi Nobel Indonesia. 